\title{
Herbal Supplements or Herbs in Heart Disease: Herbiceutical Formulation, Clinical Trials, Futuristic Developments
}

\author{
*Rakesh Sharma ${ }^{1}$ and Arunporn Itharat ${ }^{2}$ \\ ${ }^{1}$ Department of Exercise, Nutrition and Food Science, Florida State University,Tallahassee, USA \\ ${ }^{2}$ Department of Traditional Medicine, Thammasat University, Thailand
}

Submission: December 27, 2016; Published: January 20, 2017

*Corresponding author: Rakesh Sharma, 3945 West Pensacola Street, Suite 98, Tallahassee, FL 32304, Phone: 011917534899120;

Email: rksz2009@gmail.com

\begin{abstract}
Herbal formula serves the purpose of alternative or combinatorial treatment as safe, cheap and effective complementary and alternative medicine with no side effect. Coronary Heart Disease (CHD) and Cardiovascular disease (CVD) are major disorders of dyslipidemia or elevated lipids in blood to result with atherosclerosis and cardiac arrest. Biochemical mechanistic basis of changes in cardiovascular metabolites and regulation is described. New non-invasive herbal testing method is described based on in vivo magnetic Resonance Imaging and ex vivo Magnetic Resonance Microscopy - histology correlation. A scheme of herbal testing method is presented based on herbal induced change in physical symptoms, clinical diagnosis, experimental evaluation of herbal effects on heart biochemical and physiological functions. Herbal foods and herbal preparations are approved to benefit public for cardiovascular disease prevention. It remains to see if herbal medicine reduces or arrests the cardiovascular injury without any long-term side effects under skepticism of 'really herbs can work'
\end{abstract}

Keywords: Heart Disease; Coronary; Herbal; Herbs; Cardiac Arrest; Lipid

Abbreviations: CVD: Cardio-vascular Disease; CHD: Coronary Heart Disease; RDA: Recommended Daily Allowances; AMIL: Acute Myocardial Infarction; MUFA: Mono-unsaturated Fatty Acid; AHA: American Heart Association; VCAM-1: Vascular Cell Adhsion Molecule-1; CRP: C-Reactive Protein, IL-6: Interleukine-6; TNF- $\alpha$ : Tumor Necrosis Factor- $\alpha$; SAA: Serum Amyloid A; HDL: High Density Lipoprotein; COX: Cyclooxygenas, 5-LOX: 5-Lipoxygenase; TxA 2: Thomboxane-2; PGI: 2 Prostacyclin I2; LTB 5: Leucotriene B5; LPL: Lipoprotein Lipase; HNF: Hepatic Nuclear Factor; LXR: Liver X Receptors; PPARs: Peroxisome Proliferators-Activated Receptors; SREBPs: Sterol Regulatory Element Binding Proteins; PUFAs: Polyunsaturated Fatty Acids; CAM: Complementary and Alternative Medicine; NHLI: National Heart and Lung Institute

\section{Introduction}

In present report, we introduce readers to the emerging knowledge on use of herbs in cardiac protection, mechanism of dyslipidemia in development of heart disease and our new technique of non-invasive micro imaging of heart disease. The scope of herbal treatment is wider initially to manage dyslipidemia by lipid lowering and enhancing 'cardiac capacity' in cardio protection and cardiac prevention. Prevention of disease includes hypertension, coronary heart disease, cerebrovascular disease, peripheral vascular disease, heart failure, rheumatic heart disease, congenital heart disease, cardiomyopathies. Chapter is divided into different sections on present state of art in herbal formula in cardio protection, introduction to herbs in heart disease, biomarkers and biochemistry of herbal cardio protective action, herbiceutical formula, and future prospective of herbiceuticals in cardio protection with a comment on government policy.

\section{Herbiceutical formula in Heart Disease Treatment}

In following section, we describe available herbiceuticals to treat coronary heart disease. The following description is modified from its original sources [1].

Herbal Formula 1: San-Huang-Hsie-Hsin-Tang® is prepared from scutellaria root (Radix Scutellariae): rhizome of coptis: root and rhizome of rhubarb (Radix et Rhizoma Rhei): Radix Ginseng (root of ginseng) mix in ratio of $1-2: 1-2: 1-2: 1-2$ or $1: 1: 1: 1$ in $95 \%$ ethanol.

a. Scutellaria Plant: All four ingradients are extracted, filtered and made mixture to form an herbal pill. Herbal pill 
can stabilize and lower blood pressure or prevent damage to endothelial cell by inhibiting intrinsic nitric oxide (iNOS) activity, inhibiting cyclo-oxygenase- 2 or COX-2 activity, reducing blood C-reactive protein concentration, inhibiting smooth muscular cells proliferation, reducing blood cholesterol level in all ages and elderly. The mechanism of herbal pill to prevent heart disease can be described in three reactions:

b. NO produced in endothelium by eNOS is potent vasodilator and inhibits platelet aggregation, smooth muscle cell proliferation, monocyte adhesion and adhesion molecule expression, thus, maintain integrity of endothelial tissues;

c. Production of COX-2 dependent factors-prostanoids and oxygen free radicals in myocardial issue are due to endothelial dysfunction or vascular damage. Inhibition of COX-2 may restore NO mediated vasodilation, antiinflammatory utility;

d. Overexpression of iNOS leads to the increased NO production and causes myocardial dysfunction, congestive heart failure and cardiac arrest;

e. C-reactive protein is formed in inflammation process and atherosclerosis with prevalent CHD, stroke and peripheral artery disease. Scutellaria has ingradients of baicalin, oroxylin, A-glucuronide, wogonin-7-0-glucuronide, baicalein, wogonin, oroxylin A. Ample evidences show that Scutellaria inhibits NO production, depresses COX2 production, and reduces iNOS overexpression and C reactive protein (Table 1 ).

Table 1: Major Ingradients of cardio protective herbs and herbal formula composition.

\begin{tabular}{|c|c|c|c|c|}
\hline \multicolumn{5}{|c|}{ Herbs of the Present Pharmaceutical Composition } \\
\hline Pharmaceutical Name & Botanical Name & Family & Common Description & Major Ingredients \\
\hline Radix Scutellariae & $\begin{array}{l}\text { Scutellaria baicalensis } \\
\text { Georgi }\end{array}$ & Labiatae & scutellaria or scute & $\begin{array}{c}\text { Baicalein, baicalin, } \\
\text { wogonin, wogonin-70- } \\
\text { glucuronide, neobaicalein, } \\
\text { oroxylin A glucuronide, } \\
\text { camphesterol, } \beta \text {-sitosterol, } \\
\text { benzoic acid }\end{array}$ \\
\hline Rhizoma Coptidis & $\begin{array}{l}\text { Coptis chinensis Franch., } \\
\text { C. deltoidea C. Y. Cheng } \\
\text { C. omeiensis (Chen) C. Y. } \\
\text { Cheng or C. teetoides C. Y. } \\
\text { Cheng }\end{array}$ & Ranunculaceae & coptis rhizome & $\begin{array}{c}\text { berberine, coptisine, } \\
\text { worenine, palmatine, } \\
\text { columbamine, } \\
\text { obacunone, obaculactone, } \\
\text { palmatine, jatrorrhizine, } \\
\text { magnoflorine, ferulic acid }\end{array}$ \\
\hline Radix et Rhizoma Rhei & $\begin{array}{l}\text { Rheum palmatum L. or } \\
\text { R.tanguticum Maxim. et } \\
\text { Reg. (used in north China) } \\
\text { or R. officinale Baill. (used } \\
\quad \text { in south China) }\end{array}$ & Polygonaceae & rhubarb root and rhizome & $\begin{array}{l}\text { derivatives of } \\
\text { anthraquinone glycosides } \\
\text { including chrysophanol, } \\
\text { emodin, aloe-emodin, } \\
\text { rhein, and physcion, } \\
\text { rheum tannic acid, gallic } \\
\text { acid, catechin, tetrarin, } \\
\text { glucogalin, cinnamic acid, } \\
\text { rheosmin, fatty acids, } \\
\text { calcium oxalate, glucose, } \\
\text { fructose, sennoside A,B, } \\
\text { and C }\end{array}$ \\
\hline Rhizoma Zingiberis & Zingiber officinale Roscoe & Zingiberaceae & ginger, ginger rhizome & $\begin{array}{l}\text { gingerol, shogaol, and } \\
\text { Zingerone }\end{array}$ \\
\hline Radix Panacis Quinquefolli & Panax quinquefolium L. & Araliaceae & American ginseng & Saponins, panaquilon \\
\hline Radix Ginseng (Rubarb) & Panax ginseng C. A. Mey & Araliaceae & ginseng, red ginseng & $\begin{array}{c}\text { panaxatriol, panaxadiol, } \\
\text { other panoxisides, } \\
\text { panoquilon, panaxin, } \\
\text { ginsenin, } \alpha \text {-panaxin, } \\
\text { proto panaxadiol, proto } \\
\text { panaxatriol, panacene, } \\
\text { panaxynol, panaenic } \\
\text { acid, panose, danmarane, } \\
\text { glucose, fructose, maltose, } \\
\text { sucrose, nicrotinic acid, } \\
\text { riboflavin, thamine }\end{array}$ \\
\hline
\end{tabular}


*SunTen ${ }^{\circledR}$ Cardiovascular Drug is made from 20 grams of each root of scutellaria, rhizome of coptis, root/rhizome of rhubarb. All ingradients were boiled, extracted, filtered, condensed, reflexed in ethanol to make dry powder containing the following herbs and chemicals shown in (Table 2).

Table 2: HPLC Retention times and wave lengths of different ingredients in SunTen $\circledast$ formula.

Table 2A: HPLC Conditions: Guard column: Lichrospher RP-18 endcapped 5 pm, 4.0, ID x 10 mm, Merck, German, Column+Cosmosil 5C18 MS $(5 \mu \mathrm{m}, 4.6$ ID $\times$ 250, Nacalai tesque, Japan: Column temperature $35^{\circ} \mathrm{C}$; Moble phase: $\mathrm{KH}_{2} \mathrm{PO}_{4} / \mathrm{H}_{2} \mathrm{PO}_{3}$ : Acetonitrile: Water.

\begin{tabular}{|c|c|c|}
\hline \multicolumn{3}{|c|}{$\begin{array}{c}\text { Retention Times and Wavelengths of the Ingredients in } \\
\text { Scutellaria }\end{array}$} \\
\hline Compound & $\begin{array}{l}\text { Retention time } \\
\text { (minutes) }\end{array}$ & $\begin{array}{c}\text { Maximum } \\
\text { absorption } \\
\text { wavelength }\left(\lambda_{\max }\right)\end{array}$ \\
\hline Baicalin (BG) & $\sim 30$ & $276 \mathrm{~nm}$ \\
\hline $\begin{array}{l}\text { Oroxylin A- } \\
\text { glucuronide }(\mathrm{OG})\end{array}$ & $\sim 36$ & $269 \mathrm{~nm}$ \\
\hline $\begin{array}{l}\text { Wogonin-7-0- } \\
\text { glucuronide (WG) }\end{array}$ & $\sim 39$ & $272 \mathrm{~nm}$ \\
\hline Baicalein (B) & $\sim 51$ & $275 \mathrm{~nm}$ \\
\hline Wogonin (W) & $\sim 56$ & $274 \mathrm{~nm}$ \\
\hline Oroxylin A (0) & $\sim 57$ & $269 \mathrm{~nm}$ \\
\hline
\end{tabular}

Table 2B: HPLC Conditions: Guard column: Lichrospher RP-18 endcapped 5 pm, 4.0, ID x 10 mm, Merck, German, Column+Cosmosil 5C18 MS $(5 \mu \mathrm{m}, 4.6$ ID $\times$ 250, Nacalai tesque, Japan: Column temperature $35^{\circ} \mathrm{C}$; Mobile phase: Buffered acetonitrile: water.

\begin{tabular}{|c|c|c|}
\hline Retention Times and Wavelengths of the Ingredients in Coptis \\
\hline Compound & $\begin{array}{c}\text { Retention time } \\
\text { (minutes) }\end{array}$ & $\begin{array}{c}\text { Maximum } \\
\text { absorption } \\
\text { wavelength }\left(\boldsymbol{\lambda}_{\max } \text { ) }\right.\end{array}$ \\
\hline $\begin{array}{c}\text { Berberastine } \\
\text { (Berber) }\end{array}$ & $\sim 17$ & $264 \mathrm{~nm} ; 357 \mathrm{~nm}$ \\
\hline Columnbamine (Col) & $\sim 21$ & $264 \mathrm{~nm} ; 345 \mathrm{~nm}$ \\
\hline Jatrorrhizine (Jat) & $\sim 21.5$ & $264 \mathrm{~nm} ; 345 \mathrm{~nm}$ \\
\hline Epiberberine (Epi) & $\sim 22.5$ & $267 \mathrm{~nm} ; 357 \mathrm{~nm}$ \\
\hline Coptisine (Cop) & $\sim 23.5$ & $264 \mathrm{~nm} ; 358 \mathrm{~nm}$ \\
\hline Palmatine (Pal) & $\sim 26$ & $272 \mathrm{~nm} ; 345 \mathrm{~nm}$ \\
\hline Berberine (Ber) & $\sim 27$ & $263 \mathrm{~nm} ; 347 \mathrm{~nm}$ \\
\hline
\end{tabular}

Table 2C: HPLC Conditions: Guard column: Lichrospher RP-18 endcapped 5 pm, 4.0, ID x 10 mm,Merck, German, Column: Symmatry shield RP18 (5 $\mu \mathrm{m}, 4.6$ ID x 250, Waters, USA: Column temperature $40^{\circ} \mathrm{C}$; mobile phase: Acetoacetic acid, Acetonitrile.

\begin{tabular}{|c|c|c|}
\hline Retention Times and Wavelengths of the Ingredients in Rhubarb \\
\hline Compound & $\begin{array}{c}\text { Retention time } \\
\text { (minutes) }\end{array}$ & $\begin{array}{c}\text { Maximum } \\
\text { absorption } \\
\text { wavelength }\left(\boldsymbol{\lambda}_{\text {max }} \text { ) }\right.\end{array}$ \\
\hline Sennoside B (SB) & $\sim 38$ & $268 \mathrm{~nm}$ \\
\hline Sennoside A (SA) & $\sim 46$ & $269 \mathrm{~nm}$ \\
\hline Aloe-emodin (AL) & $\sim 72$ & $277 \mathrm{~nm}$ \\
\hline Rhein (RH) & $\sim 87$ & $257 \mathrm{~nm}$ \\
\hline Emodin (EM) & $\sim 92.5$ & $287 \mathrm{~nm}$ \\
\hline
\end{tabular}

Formula 2: Mixture of four: Danshensu (Salvia miltiorrhiza Bge.) chemical formula $\mathrm{D}(+) \beta$-(3,4-dihydroxyphenyl)lactic acid], Tanshinone IIA, matrine (Sophorea flavescens Ait.), oxymatrine (Radix sophorae Flavescentis), puerarin (Pueraria lobata Phwi.). Four herbs are mixed in ratio of 1:1:1:1 to prepare an herbal mixture to treat the atherosclerosis or obstructed the blood supply to heart. The mechanism of cardio protection might be explained as inhibition of blood platelet accumulation and blood fibrin dissolution; vasodilatation and relieving smooth muscle spasm in myocardium muscle; improved myocardial muscle metabolism under anerobic condition and reducing ATP consumption as protective measure; inhibiting the peroxidation reaction or clearance of free radicals and fatty deposits; inhibiting blood platelets and improving cell membrane mobility; increasing cAMP in cardiac muscle to tolerate glucose and oxygen insufficiency; strengthen immune system; increased vasodilatation and blood flow.

For partial details of cardiac protection outcome in experimental animals, readers are referred to read patents including herbal mixture testing by cardiac enzymes, ventricular function, right-left atrial driving force or anti-arrthymicity, LVSD, beta receptor of adenylate cyclase [2] to prove the following:

a. herbal mixture acts as anti-myocardial infarction protection of vascular epithelial tissue;

b. herbal mixture reduces Angina pectoris and endothelin-1 along with decalcification gene related protoplasm (cGRP) induced dilatation of blood vessels;

c. herbal mixture reduces platelet agglutination and atheroma to resist myocardial infarction.

d. We describe following heart protection formula using Radix Salviae Miltorrhizae and it is extract described in its original source [3].

Formula 3: Herbal Pill of 80.0-97.0\% Radix Salviae Miltorrhizae, $1.0-19.0 \%$ Panax Notoginseng and 0.1-1.0\% Borneol and its active ingredients was invented by following steps:

a. Obtaining an appropriate amount of smashed Radix Salviae Miltorrhizae and Panax Notoginseng;

b. Extracting the obtained Radix Salviae Miltorrhizae, and Panax Notoginseng in hot aqueous reflux at about $60-100{ }^{\circ} \mathrm{C}$;

c. Filtering and combining the extracts to form a combined extract;

d. Concentrating the combined extract from step (c) into an appropriate ratio of the volume of the concentrated extract to the weight of the inputted herbal materials to form a concentrated herbal extract;

e. Putting ethanol into the concentrated extract from step (d) to about $50-85 \%$ final concentration of ethanol, performing ethanol precipitation and forming a precipitated 
resolution;

f. Concentrating the supernatant liquid of the precipitated resulting from step (e) to form a plaster of about 1.15-1.45 in relative density; and

g. Mixing the plaster from step (f) with an appropriate amount of Borneol, thereby producing the composition of herb extract of Radix Salviae Miltorrhizae, Panax Notoginseng and Borneol. The active ingredient extracted from Salvia miltiorrhiza Beg. contains one or more ingredients selected from tanshinone, salvianolic acid, methyl tanshinonate, rosmarinic acid, methyl rosmarinate, danshexinkum, protocatechualdehyde, Sodium 3'4-dihydroxyphenyllactate, and lithospermic acid. The ingredient extracted from Panax notoginseng or Ginseng contains one or more ingredients selected from notoginsenoside and ginsenoside. The ingredient extracted from Dryobalanops aromatica Geartu. F. or Cinnammon camphor contains d-borneol or l-borneol or both of them.

Herbal pill preparation was performed by:

a) Mixing the extracts of Panax Notoginseng, the extracts of Radix Salviae Miltorrhizae, synthetic borneol, and polyethylene glycol 6000 at the ratio of 4.0:20.6:1.9:79.5;

b) Melting the mixture;

c) Manufacturing the melted mixture to pills using a dropping machine with the following characteristics:

i. $\quad$ The temperature of the dropping pot is constantly 89$93^{\circ} \mathrm{C}$;

ii. The cooling solution is liquid paraffin, of which the temperature is lower than $8{ }^{\circ} \mathrm{C}$.;

iii. The inner diameter of the dropping head is $1.8 \mathrm{~mm}$, the outer diameter of the dropping head is $2.4 \mathrm{~mm}$, the distance between the dropping head and the surface of the cooling solution is $15 \mathrm{~cm}$; and (d) centrifugation of the pills at 800 $1100 \mathrm{rpm}$ for 15 minutes to remove oils (Table 3).

Table 3: HPLC Conditions: Guard column: Lichrospher RP-18 endcapped 5 pm, 4.0, ID x 10 mm, Merck, German, Column+Cosmosil 5C18 MS (5 $\mu \mathrm{m}, 4.6$ ID $\times$ 250, Nacalai tesque, Japan: Column temperature $35^{\circ} \mathrm{C}$; Moble phase: $\mathrm{KH}_{2} \mathrm{PO}_{4} / \mathrm{H}_{2} \mathrm{PO}_{3}$ : Acetonitrile: Water.

\begin{tabular}{|c|c|c|}
\hline Retention Times and Wavelengths of the Ingredients in Ginseng \\
\hline Compound & $\begin{array}{c}\text { Retention time } \\
\text { (minutes) }\end{array}$ & $\begin{array}{c}\text { Maximum } \\
\text { absorption } \\
\text { wavelength }\left(\lambda_{\max }\right)\end{array}$ \\
\hline Ginsenoside $\mathrm{R}_{\mathrm{g} 1}\left(\mathrm{R}_{\mathrm{g} 1}\right)$ & $\sim 23.5$ & $204 \mathrm{~nm}$ \\
\hline Ginsenoside $\mathrm{Re}$ & $\sim 23.8$ & $203 \mathrm{~nm}$ \\
\hline Ginsenoside $\mathrm{R}_{\mathrm{b} 1}\left(\mathrm{R}_{\mathrm{b} 1}\right)$ & $\sim 38.5$ & $203 \mathrm{~nm}$ \\
\hline
\end{tabular}

The herbal pill ingredients were capable of: increasing blood volume in the coronary artery, relaxing the smooth muscles of blood vessels, improving peripheral circulation, raising the oxygen content in veins, or significantly improving the acute myocardial ischemia or myocardial infarction, protecting the cells from damage by hypoxia or anoxia, protecting cells suffering from myocardial ischemia, improving micro-circulation, preventing arrhythmia, platelet aggregation and thrombosis, dissolving fibrin, lowering blood viscosity, adjusting blood cholesterol or preventing atherosclerosis, raising tolerance to hypoxia or anoxia, preventing the oxidation of lipoprotein or removing the harmful free radicals, lowering plasma ET content, significantly improving liver, kidney and pancreas function, preventing the occurrence or development of blood vessel or nerve diseases, enhancing the immune system, regulating vascular nerve balance $[4,5]$.

\section{Treatment of Coronary Heart Disease with herbal pill}

Following description is a glimpse of continuous trials in the direction of combinatorial therapy to reduce the risk of CHD $[1,2,4,5]$.

i. Ordinary Treatment of Coronary Heart Disease: After herbal pill became available in the market in China, treatment was proposed basically similar to that of Isordil and there is no significant difference between them statistically in treatment of CHD.

ii. Pain-killing Effects of herbal pill on Coronary Heart Disease prevention was comparable with Glyceryl Trinitrate.

iii. Effects of herbal pill on the Onset of Coronary Heart Disease, Heart Pain Frequency: Herbal pill can reduce onset frequency and volume of glyceryl trinitrate. Pill can improve blood flow to the heart in addition to relieving pain.

iv. Improvement of Blood Pressure and Cardiac Function in Patients with Coronary Heart Disease: Herbal pill can improve cardiac function in patients with coronary heart disease and provides improvements in blood flow.

v. Effects of herbal pill on ECGs and Blood Flow in Patients with Coronary Heart Disease: No significant differences appeared on ECGs and average exercise testing standards to show improvement from herbal pill. Pill controls irregular blood flow, lowers blood viscosity, reduces the occurrence of atherosclerosis, and prevents thrombosis and can be the first choice for the treatment of coronary heart disease.

vi. Effects of Long-term herbal pill Treatment on Coronary Heart Disease: Long-term herbal pill results are stable. Herbal pill is a multi-level, multi-subjected and multi-method medicine which improves cardiac muscle; increases blood volume by blocking the chronic calcium route; stabilizes the myocardial membrane; removes free radicals; regulates myocardial cells metabolism; improves blood platelets aggregation; and lowers cholesterol and blood viscosity.

vii. Clinical Research on the Effects of herbal pill on Unstable-type Angina: The experiment shows that herbal pill can reduce oxygen consumption by cardiac muscles, improve blood flow in coronary arteries, and rebalance the 
oxygen demand-to-oxygen supply ratio in cardiac muscles.

viii. The Effects of herbal pill on the Treatment of Exertiontype Angina: Herbal pill can efficiently relieve pain and increase blood flow to the cardiac muscle. Herbal pill can also reduce oxygen consumption, improve blood flow to the coronary artery, rebalance oxygen demand and oxygen supply, and prevent atherosclerosis. It is reported as ideal medicine for the prevention or treatment of coronary heart disease, angina and atherosclerosis.

\section{Herbiceutical Testing}

Following strategy is used in development, testing and approval of new herbal formulas.

i. Preparation of herbal plant extraction: herbs like scutellaria, coptis, and rhubarb are extracted by solvent (water or organic solvent 95\% ethanol).

ii. Separation, filtration: Extracts are filtered. Individual herbal extracts are filtered and condensed under reduced pressure in water bath at $50 \stackrel{\circ}{ } \mathrm{C}$ to make herbal paste.

iii. Preparation of powders: American ginseng or ginger are prepared powder by solvent extraction (cutting in pieces, grinding, drying) and passing through sieve.

iv. Herbal pharmaceutical mixture: Herb dry powders are mixed in herbal paste and dried to prepare as tablets, bolus, powder, capsule, granule using binder, carrier, and filler.

v. Experimental Animal models: A. Blood pressure lowering properties (BP, heart rate on multifunction recorder) compared in spontaneous hypertensive rats were given herbal mixture through catheter in femoral artery and compared with captoril or nifedipine given in same way; B. In other set of animals, heart rate, systolic/ diastolic BP, mean arterial BP were compared in elderly aged animals. Isolated perfused hearts with Kreb's Henselein buffer containing herbal mixture were used for measuring coronary flow and coronary perfusion pressure; C. COX-2 and iNOS enzyme synthesis in mouse macrophage cells was induced by lipopolysaccharides and both COX-2 and iNOS were measured by ELISA. COX- 2 and iNOS enzyme protein biosynthesis can be measured in excised tissues by antibody based PAGE electrophoresis; D. herbal induced inhibition of iNOS gene expression was measured by tissue RNA extraction, mixing iNOS primer with cDNA and amplifying DNA mixture by PCR and running DNA separation on agarose gel; D. Herbal induced CRP reduction in hypertensive animals was measured by ELISA in blood after centrifugation.

The following description is a glimpse on proposed guideline to design a research protocol of herbal cardioprotection assessment that includes physical signs, symptoms, preclinical lab tests, cardiac monitoring, follow up of relevant changes in cardiovascular and heart territories as possible recovery signs.
It is helpful to all researchers, physicians, policy makers.

Pre-Clinical trial: In Congestive Heart Failure (CHF) rat experimental animals, following parameters can be tested:
a. LD50 dosage determination;
b. myocardial total ischemia burden (TIB),
c. blood/plasma RT
d. release of nitrogen monoxide (NO),
e. serum superoxide dismutase (SOD) and MDA,
f. Vascular endothelin ET-1 release.
g. decalcification gene related protoplasm (cGRP)

\section{Symptoms:}

a) palpitation, tightness of chest, coughing, chest front pain, shortness of breath paroxysmal breathing difficulty at night, fatigue and weak, upper body pain and discomfort, sweating, night sweating, coldphobia and few urine.

b) physical manifestation: heart rate and heart rhythm, blood pressure, breathing, lips cyanosis cervical vein expanded, lungs wheezing, thorax water stagnant, abdominal distension, liver enlarged, edema of lower limbs, head and face dropsy.

c) Improved cardial function index: heartbeat volume (SV), cardial output (CO), cardial index (CI), cardial emission fraction (EF), left ventricle end diastole volume (LVEDV),

d) Higher contents of Malonyl dialdehyde (MDA), ANPSOD, superoxide dismutase (SOD), GSH-Px and ANP after herbal treatment.

e) Improved systolic capacity of cardial muscle by measuring left ventricle systole pressure value (LVSP), left ventricle maximum systole speed rate $(+\mathrm{dp} / \mathrm{dt})$ and left ventricle minimum systole speed rate $(-d p / d t)$.

f) With regard to animal experiment, pathological slice of animal model's heart hypertrophy of left ventricle myocardial cells; muscular tissue breaks; inflammation by histology-MR microscopy.

g) TIB ischemic burden

Clinical trial: In patients recruited on WHO criteria of hypertrophic cardiomyopathy with angina pectoris confirmation by straight $\mathrm{T}$ wave (improved strium and ventricular contraction; reduced ET-1 and rise in cGRP; high coagulation or low platelet agglutination
a. SOD activity and reduced MDA density
b. $\quad$ Reduced ET-1
c. rise in cGRP comparison Decalcification Related Protoplasm(cGRP) 
d. Angina pectoris in A-->D grades.

e. Sex, age, disease course, angina pectoris types, degree of seriousness of angina pectoris

f. Irregular heart rhythm and diabetic complication

g. liver and renal function, electrocardiogram for tall $\mathrm{T}$ wave and suppressed ST section

\section{Technique development in noninvasive micro imaging of thrombosis and measurement of heart disease}

With advancement of science, now noninvasive imaging modalities are in use to detect measure and monitor the prognosis and progress of heart disease condition before and after intervention. Coronary artery wall thickness and myocardium shape are two major territories used in assessment of heart disease burden. Magnetic resonance imaging, ultrasound scanning of heart is choices to measure thrombosis and cardiac function respectively. We established the cytomorphic and molecular markers of heart as measurable index in different territories using Magnetic Resonance Microscopy; nanoparticle based molecular targeting in order to test cardio protective herbal, nutraceutical and pharmaceutical drugs.

Our new technique of drug testing includes: multiple contrast in vivo heart MRI/MRA, ex vivo delayed ultrahigh magnetic field MRI, and histopathologic-MRI correlation data as reported previously. Our major focus was to develop high diagnostic accuracy in non-invasive identification of plaque contents and heart territories by MR microscopy with structural details as shown in Figures 3-6. For details, readers are referred to read original sources [6,7] (Figures 1-3).

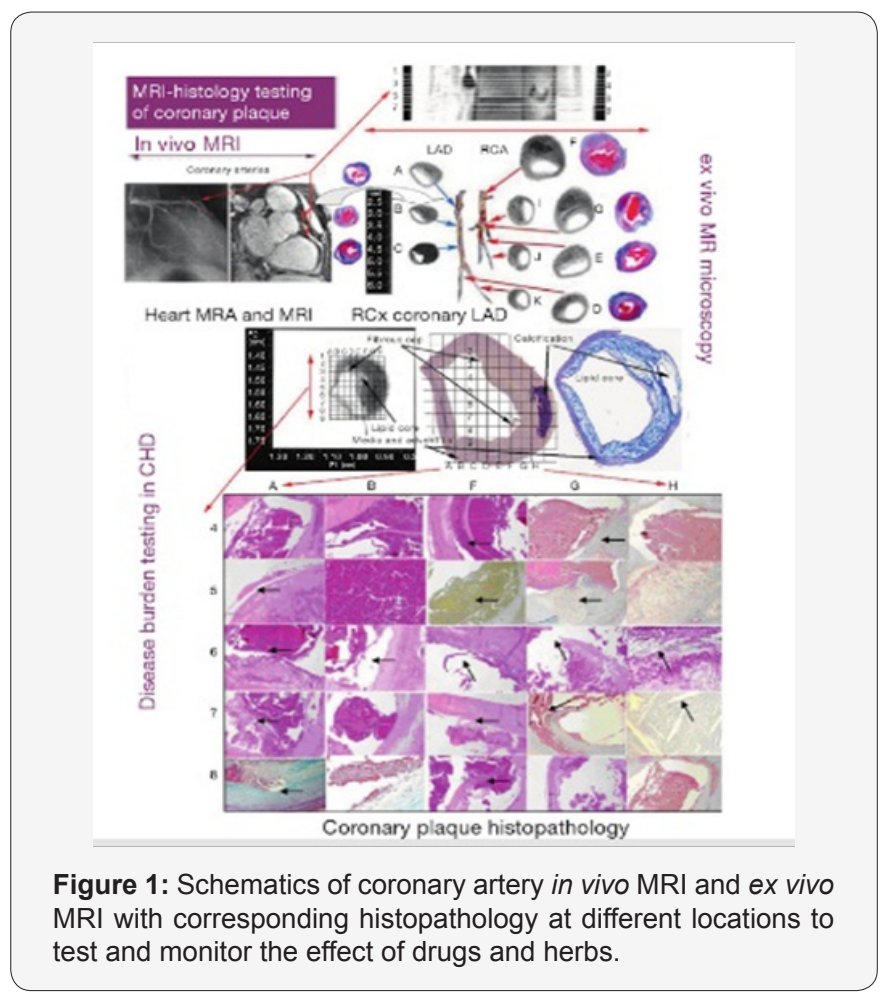

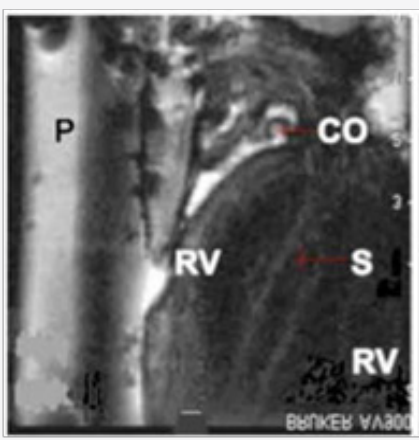

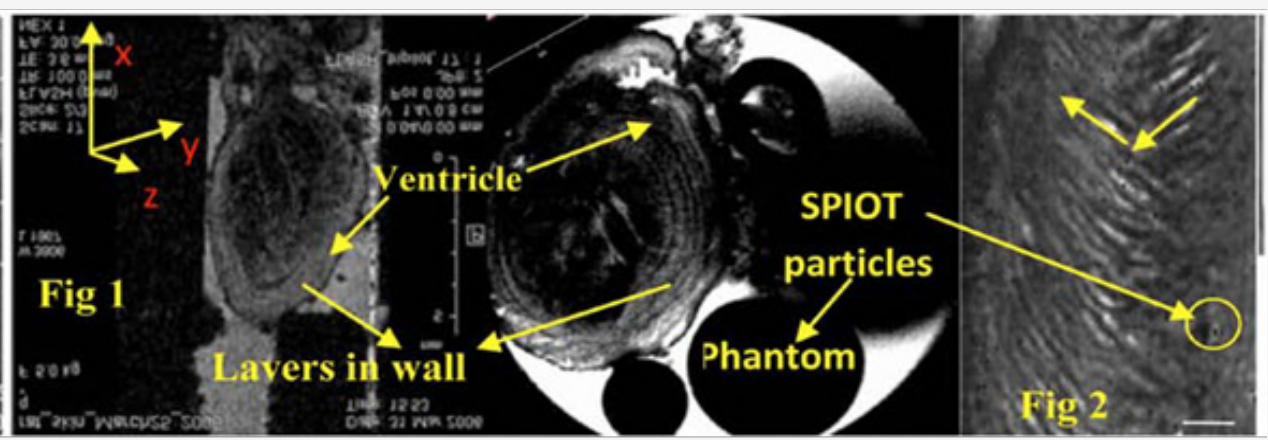

Figure 2: New Nanoparticle based NMR microscopy technique to test herbs and drug on cardiac muscle structural-functional properties. Reproduced with permission.
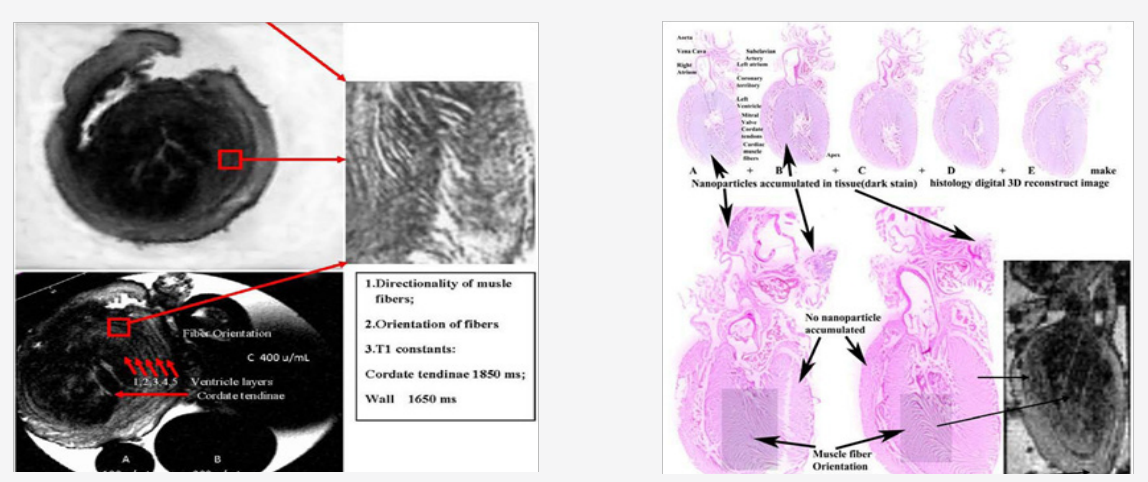

Figure 3: Herbal and drug testing of heart muscles and heart structures by ex vivo MRI and corresponding ex vivo Histopathology to observe cytomorphic changes in cardiac structures Reproduced with permission. 


\section{Strategy of cardio protection}

We describe heart protection and preventive herbal action as anti-fibrillation, antihypertensive and anti-thrombosis which essentially includes minimizing lumen space, wall thinning and strengthening cardiac muscles in following sections based on imaging strategy for CHD $[3,8]$.

Three main goals are accomplished to keep heart healthy are:

a. Opening Blood Vessels

b. Strengthening the Heart Muscle

c. Controlling Free Radical Damage -- Antioxidants

\section{Biomarkers in Evaluation of Herb testing}

Herbal testing is a standard procedure using different biomarkers as shown schematics in (Figure 4) to evaluate herbal response to improve cardiac recovery. The following reports are extracted from original sources for readers in both pre-clinical and clinical herbal trials $[2,5,6]$.

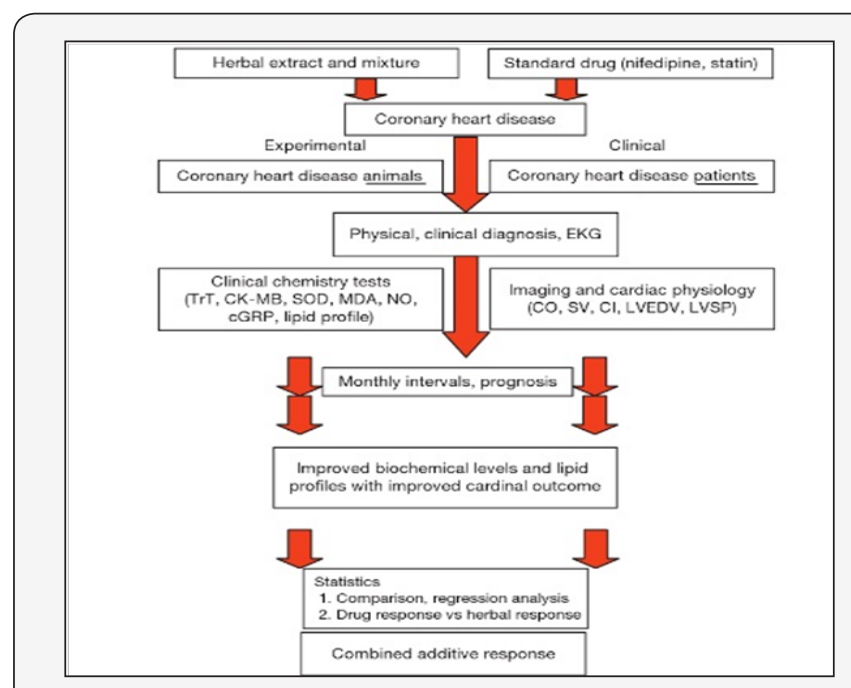

Figure 4: An algorithmic approach is shown to test herb medicine cardiac response and prepare it for combination Herbal-chemotherapy treatment.

Anti-Myocardial Infarction Protection of Vascular Epithelial heart Tissue in patients: The observation includes counting clinical symptom before and after herbal treatment, for the changes of myocardial total ischemia burden (TIB), blood plasma endothelin (ET), decalcification gene related protoplasm (cGRP), nitrogen monoxide (NO), superoxide dismutase (SOD) and MDA as biomarkers. TIB is done with Holter inspection. Before and after herbal intervention, venous blood is drawn for determining plasma RT, NO, density of serum SOD and MDA, changes of TIBN. With regards to the herbal treatment of blood shortage heart disease, it is important to improve myocardial blood shortage effectively to the utmost extent, to restore and protect vascular oxygen shortage in vascular epithelial cells from being oxygen resupply damaged. The role of these biomarkers is described in following section.

i. Vascular endothelin is strongandlasting polyprotoplasm that shrinks vascular byczenol. Its primary biological effects are: multi-functions such as shrinking vascular plain muscle, stimulating breeding of cells, inhibiting release of renal hormone, strengthening depotassium adrenaline and vascular nervous hormone II, refining vascular amino acid inhibition hormone, matter revolving, self-secretion and side-secretion. In fact, it plays an important role in the biological and pathological process of cardiac and cerebral vascular diseases like those of restoring damage, generating blood vessel and formation of thrombosis. However, from the biological standpoint, vascular epithelial tissue is also the most vulnerable functional interface. It can be affected by various pathological situations, and creates morphological and biochemical changes. Damage of vascular epithelial tissue is the main mechanism of increasing ET release. Its excessive release can lead to coronary artery convulsion, myocardial blood shortage and even necrosis. Thus, reducing ET is an important means to protect myocardium health.

ii. Decalcification gene related protoplasm (cGRP) is a byczenol polyprotoplasm that dictates blood vessels. It leads to dropping of blood pressure and strong diastolic capillary function. It is able to prevent tissues of heart, brain, kidney from damage of blood shortage and reconcentration. It protects myocardium from shortage of blood, damage and enhances myocardium systole and cardial discharge capacity (reduced flare up of heart rhythm, ET-1) to strengthen vascular resistance and breeding of muscle cells.

iii. NO has the capability of dilating blood vessels, reducing blood pressure, inhibiting platelets adherence and polymerization. It has the most significant function of safeguarding regular cardiac of maintaining myocardial blood flow. It is able to resist the vascular systole effect of ET. It is an internal myocardial protective substance. Two different biological effects take part in the adjustment of cardiac vascular function and the flare up process of coronary disease. Therefore, protect vascular epithelial tissue from being damaged, inhibit effectively secretion of ET-1, improve release of NO, adjust plasma density balance of both in order to improve the supply of blood and oxygen to myocardium. These are the important means of treating coronary heart disease.

iv. Reduction of plasma ET density and the obvious rise of plasma NO indicate the positive adjustment function on internal vascular active substance and metabolism of cardiac protective substance. In myocardial blood shortage, herbal mixture has function of good protect and restoration on damage of vascular epithelial tissue or anti-myocardial blood shortage as protective effect of vascular epithelial tissue. 
v. Myocardial blood shortage of coronary heart disease, damage of blood shortage refilling has increased lipoperoxide reaction to cause oxygen unrestrained base in vascular epithelial tissue. Anti-oxidation or superoxide anion scavenger herbal action is the protection functions for vascular epithelial tissue damage and myocardial blood shortage.

vi. To enhance blood circulation, improve blood later developments, resist fibro-solvent thrombosis of hemolysis, dilate coronary artery, remove spasm of minor artery and increase blood flow capacity of coronary artery indicated by rise of SOD activity and reduced MDA density in conjunction with lipoperoxide removal as internal and external antioxidant.

Coronary Heart Disease, Angina Pectoris, Change of Endothelin-1 and Decalcification after herbal treatment: The following symptoms may be evident of herbal protection:

i. Angina pectoris existing in A-->D grades. Herbal treatment restricts or reverts the events of angina pectoris for longer time and symptoms disappear.

ii. Anti-hypertrophic cardiomyopathy action of herbs in CHD patients

iii. Sex, age, disease course, angina pectoris types, degree of seriousness of angina pectoris.

iv. Irregular heart rhythm and diabetic complication have comparability $(\mathrm{p}>0.05)$.

v. Clinical symptoms, physical manifestations, heart rate and blood pressure, lab test of blood, urine and stool, liver and renal function, electrocardiogram for ST section.

vi. Tall $\mathrm{T}$ wave and suppressed ST section appear after herbal treatment.

vii. Reduced ET-1 and rise in cGRP comparison $(\mathrm{pg} / \mathrm{ml} \mathrm{X} \pm$ S) of two groups after treatment.

viii. Gene Related Protoplasm(cGRP) of Pre- and PostTreatment of Herbs

ix. Endothelin (ET) is a strong and lasting polyprotoplasm with biological effects: shrinking vascular plain muscle; stimulating breeding of cells; inhibiting release of renal hormone, strengthening depotassium adrenaline and vascular nervous hormone II; refining vascular amino acid inhibition hormone. It has the inhibition function on cardial mechanism.

x. Decalcification gene related protoplasm (cGRP) is a byczenol polyprotoplasm with biological effects: dilating blood vessels; dropping of blood pressure and strong diastole function on capillaries; preventing the heart, brain, liver and kidney from damage of blood shortage and reconcentration; protecting myocardium from shortage of blood and enhances myocardium systole and cardial discharge capacity. As a result, flare up of heart rhythm can be prevented or reduced and cGRP strengthens the vascular resistance, and prevents myocardium from damage. Herbal mixture raises the plasma cGRP level.

\section{Congestive Heart Failure (CHF)}

\section{Symptoms:}

a) Palpitation, tightness of chest, coughing, chest front pain, shortness of breath paroxysmal breathing difficulty at night, fatigue and weak, upper body pain and discomfort, sweating, night sweating, coldphobia and few urine.

b) Physical manifestation: heart rate and heart rhythm, blood pressure, breathing, lips cyanosis cervical vein expanded, lungs wheezing, thorax water stagnant, abdominal distension, liver enlarged, edema of lower limbs, head and face dropsy.

II. of Herbal Mix:

a) Improved cardial function index: heartbeat volume (SV), cardial output (CO), cardial index (CI), cardial emission fraction (EF), left ventricle end diastole volume (LVEDV),

b) Higher contents of Malonyl dialdehyde (MDA), ANPSOD, superoxide dismutase (SOD), GSH-Px and ANP after herbal treatment.

c) Improved systolic capacity of cardial muscle by measuring left ventricle systole pressure value (LVSP), left ventricle maximum systole speed rate $(+\mathrm{dp} / \mathrm{dt})$ and left ventricle minimum systole speed rate $(-d p / d t)$.

d) With regard to animal experiment, pathological slice of animal model's heart hypertrophy of left ventricle myocardial cells; muscular tissue breaks; inflammation by histology-MR microscopy.

Cardio-protective Herb Active Components in Human use Approved by CDC and Regulated by FDA

The herbs are rich in different metabolites playing role in active intermediary metabolism and these are needed in body in a minimum amount daily so called recommended daily allowances (RDA) through diets or herbal supplements. Saponoin glycosides, antioxidents, flavanoids, oligomeric proanthocyanidin fractions are major players with other ingradients. Readers are referred to read other separate section on 'biochemical basis of herbiceuticals in cardiac prevention 'for details. A number of herbal active ingredients are listed below in Table 1.

\section{Pharmaceutical Approach of Herbiceutical Formula with Anti-arrhythmic Properties}

\section{Carrier of different herbiceutical components}

The said herbal mixture (formulae 1,2,3 and 4) may be used in water, saline, starch, sugar, gel, lipids, waxes, glycerol, 
solvents, oils, liquids, proteins, glycols, electrolyte solutions, alcohols, fillers, binders, emulsifiers, preservatives, buffers, colorants, emollients, sweeteners, surfactants, additives and solvents as: solid, liquid, powder, paste, gel, tablet, foam, pack, aerosol, solvent, diluent, capsule, pill, liposome, syrup, solution, suppository, emulsion, suspension, biodelivery agents. The herbiceutical mixture may be delivered through oral, injectable or external administration for treatment of: kidney, bone, blood, lymph, liver, lung, head and neck, adrenal, brain, bronchial, hypothalamus, parathyroid, thyroid, pancreas, pituitary, sinus, endometrium.

a) Controversial status: Several bioactive compounds such as CoQ2,4,6 and CoQ10; and herbs such as knotwood rhizome, elecampane root, Turkey rhubarb are less understood and their antiarrhythmic properties remain controversial. Recently, the safe use of herbiceuticals and nutraceutical supplementation formula was reviewed by author with major focus on preclinical and clinical evidences and role of regulatory federal governments on bioactive foods, herbs and use of herbiceuticals $[8,9]$.

\section{What Remains Still to Solve the Cardio protection by Herbiceuticals?}

The major issues that remain unsolved are the herbiceutical side effects, dosage and mechanism; follow up consequences and mandatory guide lines of usage. The diet and lifestyle guidelines for prevention of coronary artery disease (CAD) have been evidenced as a major interest during the Last few decades. Recommendations of the American heart Association (AHA 2007) have been reformed for better understanding, based on new scientific evidences after publication of guidelines in 2007 [10]. However, none of these guidelines emphasize the role of diet in patients with acute myocardial infarction (AMI) and stroke. Patients presenting with AMI are highly motivated to follow the advice of cardiologist due to serious AMI condition. AMI is associated with hyperglycemia, hyperinsulinemia, hypertriglyceridemia, free radical stress, rise in free fatty acid and pro-inflammatory cytokines, leading to endothelial dysfunction.

There happens an acute generation of pro-inflammatory milieu among AMI patients which is known to cause disruption of atheroma plaque, resulting into re-infarction and death. The synergy of these mechanisms in chronic disease is not clear in order to decide the intervention by herbiceuticals such as walnuts, ginko, vegetables [11-15]. Most American experts very deligently advise dietary patterns; including grains, vegetables, fruits, nuts, seeds and legumes, fat and oils based on limited research studies. Most of the times, the side effects of newly introduced products in market are not documented such as no recommendation for refined starches in the prevention of endothelial dysfunction [16].

For example, there is no guideline about the type of oil and type of nuts for omega- 3 fat and monounsaturated fatty acid
(MUFA) content in supplemented processed foods. While foods and beverages with added sugars and refined starches as well as excess of $w-6$, total and saturated fat and trans fatty acids, may be pro-inflammatory, increased intake of $\mathrm{w}-3$ fatty acid and MUFA may not be protective against surge of TNF-alpha, IL-6, IL-18 and adhesion molecules like VCAM-1(vascular cell adhsion molecule-1) and ICAM-1 caused by high glycemic, rapidly absorbed pro-inflammatory foods [17-19]. These foods are known to initiate a pro-inflammatory milieu in the body which is similar to that of AMI, causing further increase in complications among these patients [9]. In keeping these facts in mind, it is necessary to identify the concrete evidences of cardio protective mechanism in both animals and clinical trials under controlled conditions with through investigations, careful nutrition formula design and success rate vs fallacies of earlier clinical experiences in favor of herbiceuticals in public use.

\section{Animal Studies}

A large volume of literature is available on herbiceutical inhibitory effect on cardiovascular disease cell growth based on observations of cultured cardiovascular disease cell proliferation, enhanced apoptosis, antioxidant action etc. Still attempts are in the direction of morphological, cytomorphic, histopathology evidences of herbiceutical induced lipid inhibition and thrombosis by using 3D localized molecular imaging techniques. Previous studies on micro-MRI and immune staining suggested the reduced apoptosis in experimental rat, mice, rabbit, porcine, dogs experimental models [18]. Major evidence was the reduced oxidative stress, slowed down apoptosis, reduced proliferation, less plaque size, less necrosis and poor atherosclerosis growth in treated groups [20]. The mechanism of these herbiceuticals is still not established and it remains to investigate more scientifically diet controlled experimental methods [21-24].

Moreover the beneficial effects of herbiceuticals in experimental animals were reviewed and two third literature reports on herbiceuticals are documented on experimental animal cardiovascular disease studies as either reviews or animal bench experiments on cardiovascular disease prevention. The clinical evidence of herbiceutical cardiovascular disease prevention success is still based on biochemical mechanisms of nutrients in diets reported over several decades. Some mechanisms of herbiceutical action are reported as immune modulatory, induced apoptosis, removal of free radicals, inhibited cell proliferation, inhibited necrosis. New Ayurved (Indian traditional medicine) concepts are also emerging as powerful herbiceuticals in cardiovascular disease prevention [25]. The growing literature on mechanism of herbiceutical action in the cardiovascular disease is supporting the extended benefits of herbiceuticals but it further needs more investigations as described in following separate section of new literature evidences [26-28].

\section{Clinical Trials}

Singh and coworkers, 1992 used $400 \mathrm{~g}$ /day of fruits, 
vegetables and legumes in conjunction with mustard oils to decrease the risk of hypertension, diabetes and CAD in 1990s [29], similar with DART, DART II, GISSI clinical trials [30]. This diet was re-examined by DASH investigators and subsequently by other group to observe the reduced risk of hypertension in USA [31]. In further randomized, controlled intervention trial, Singh et al. [8,32] 2002, 2010, administered 400 g/day of fruits, vegetables and nuts (almonds and walnuts) and another 400g/ day of whole grains including legumes in conjunction with 25$50 \mathrm{~g} /$ day of mustard oils (ALA $2.9 \mathrm{~g} /$ day) in patients with high risk of vascular disease, which showed significant benefits $[11,33]$.

Other workers also found a beneficial effect of fruit, vegetables, nuts and $\omega-3$ fatty acids (EPA+DHA $1.8 \mathrm{~g} /$ day) rich foods to patients on risk of coronary artery disease [29,34,35]. A randomized, double blind placebo controlled trial on 300 patients after MI supplemented with EPA+DHA 3.4-3.5 g/day or corn oil showed no change. Increased intake of monounsaturated fatty acid and $\omega-3$ fatty acids have been suggested to be protective against diabetes and metabolic syndrome whereas increased consumption of transfatty acids, saturated fat and refined starches can predispose CVD. India has a rapid economic development causing increased consumption of salt, tobacco, fat, sugar, and energy in the last four decades. There is increase in per capita income, gross domestic product, food production and automobile production in the last four decades $[29,34,35]$.

This period from 1970 to 2008 has witnessed marked changes in nutraceutical rich diet and lifestyle, particularly in the urban populations among Indians. New bioactive factors have come in light of cardiovascular mechanisms likely affected by nutrients such as:

a. Iodine induced T3 and nitric oxide decreases SVR by dilation of the arterioles protein kinase akt pathway via smooth muscle relaxation through nuclear transcription mechanisms [29,34,35];

b. Fish consumption $>300 \mathrm{gm} /$ week reduced non-fatal coronary syndrome (CARDIO 2000 study) [36];

c. Transcription of the positively regulated genes (alphamyosin heavy chain (MHC) and calcium ATPase, SERCA2) both downregulate the expression of negatively regulated genes (beta-MHC and phospholamban) to increase cardiac contractile performance. There is possibility of nutraceutical protection to repair cardiac contractility and improved ejection time (LVET) [36,37];

d. improved cardiac output, reduced cardiac preload (low rennin state and decreased erythropoietin secretion), increased vascular resistance, bradycardia, slightly depressed myocardial contractility and some increase in LV mass [38];

e. IF channel, L-type and T-type calcium channel, potassium channel and the ryanodine channel contribute to pacemaker functions and heart rate [39];

f. dyslipidemia due to total cholesterol and low density lipoproteins (LDL) cholesterol, triglycerides, very low density lipoproteins (VLDL), intermediatedensity lipoproteins, apoprotein A-1 and apoprotein B are observed as well $[40,41]$;

g. cholesteryl ester transfer protein and hepatic lipase, increased levels of high-density lipoproteins(HDL);

h. Endothelial dysfunction, increased arterial stiffness, increased vascular resistance, and hypercoagulability with coronary artery disease [42].

However the effect of bioactive foods is not known if bioactive food affects cardiovascular morbidity or mortality. It might be beneficial to use bioactive food or herbiceuticals as supplements simultaneously with cardio protective drug therapy. Recently reported noninvasive imaging methods such as Doppler echocardiography, carotid intima-media thickness, pulsed tissue Doppler imaging, and cardiac MRI and radionuclide ventriculography to evaluate pre $\mathrm{R}$ ejection/ejection ratio systolic dysfunction may be more useful to establish the beneficial effect of herbiceuticals. Overall, trials evaluating cardiovascular mortality and mortality have yielded conflicting results [43].

\section{Biochemical Basis of Herbiceuticals in Cardiac Prevention}

Natural vegetables, herbs, plants, wild foods are complex in structural composition. The biochemical basis of individual source of these foods is not explored due to their complex nature. Some of the evidences are in favor of the active food principles as herbiceuticals to show cardio protective or preventive supplements. Some of herbiceuticals are in the phase of clinical trial or already available as food supplement.

Complementary and Alternative Medicine is emerging in prevention of chronic coronary and heart diseases as safe practice because of the high risk of mortality and long-term morbidity associated with surgical procedures of coronary artery disease and high side effects of chemotherapy. Herbal medicines have shown reduced myocyte cell necrosis in cultured cells. The vitamins, minerals, dietary fat play a role in relation to cardio prevention and control. The mechanisms of herbiceutical action can be discussed broadly in following categories based on active metabolites present in herbiceuticals.

a. Niacin-bound chromium is reported to enhance myocardial protection from ischemia-reperfusion injury [44].

b. Mechanism of the antithrombotic effect was invented by dietary diacylglycerol in atherogenic mice [45].

c. Protective effect of potassium against the hypertensive cardiac dysfunction was associated with reactive oxygen 
species reduction [46]

d. The atherogenic process is reduced by regulation of coenzyme Q10 biosynthesis and breakdown.

e. The n-3 fatty acids reduce the risk of cardiovascular disease. The evidence was explained and mechanisms were explored $[46,47]$.

f. Mediterranean diet and optimal diets play role for prevention of coronary heart disease.

g. Alpha-tocopherol therapy was evidenced to reduce oxidative stress and atherosclerosis [48].

h. Genetic deficiency of inducible nitric oxide synthase reduces atherosclerosis and lowers plasma lipid peroxides in polipoprotein E-knockout mice.

i. Glutathione is the liver's most abundant protective constituent of antioxidant glutathione reductase enzyme. Glutathione functions as a substrate for the two key detoxification processes in the liver: 1 . transforming toxins into water soluble forms, 2. neutralizing and "conjugating" with toxins for elimination through the gut or the kidneys. If either of these processes is impaired for any reason, toxins will accumulate in the body and lead to disease. The best nutrition with liver cardiovascular disease focuses on improving the body's glutathione reserves [49].

j. The Soy isoflavone Haelan951 (genistein and genistin) and garlic allicin were reported to have some role as a cardioprotective in humans [50]. Beta-glycoside conjugate, genistin is abundant in fermented soybeans, soybean products such as soymilk and tofu. Beta-glycosyl bond of genistin is cleaved to produce genistein by microbes during fermentation to yield miso and natto. Soy sauce has high isoflavone but low miso and natto contents.

k. How much soy isoflavones needed? 1.5-4.1 mg/person miso isoflavone and $6.3-8.3 \mathrm{mg} /$ person natto respectively [50].

l. Green tea has always been considered by the Chinese and Japanese peoples as a potent medicine for the maintenance of health, endowed with the power to prolong life [51].

m. The cardiovascular disease has been reported associated with vascular endothelial growth factor [52].

n. Some herbal plants act as cardio protective medicine. The herbal extracts are known to reduce the circulating markers of inflammation, including C-reactive protein (CRP), interleukine-6 (IL-6), tumor necrosis factor- $\alpha$ (TNF- $\alpha$ ), serum amyloid A (SAA).

o. Combination of garlic, ginko biloba, herbs with reverastrol inhibited a full 92 percent of age-related gene changes in the heart [52].

\section{Lipid Metabolism and Fatty Acid Modifiers as Basis of CVD and role of Herbiceuticals}

Lipid metabolism is established a major factor in cardiovascular protection by supplementing omega fatty acids as described with recent developments for interested readers [8]. The possible reversal of increased total cholesterol, increased LDL cholesterol, apolipoprotein B and decreased HDL concentrations in cardiovascular patients on bioactive foods and herbiceuticals is controversial [53]. In several trials, total cholesterol levels, HDL, LDL-cholesterol, triglycerides, apolipoprotein A and B and lipoprotein A were not significantly improved with nutraceutical or vitamin-mineral treatment [53]. A trend was noted in favor of nutraceutical therapy with reduced total cholesterol TC level $>240 \mathrm{mg} / \mathrm{dL}$, LDL $>155 \mathrm{mg} / \mathrm{dL}$ TC levels (significant only for $>240 \mathrm{mg} / \mathrm{dL}$ ), and Body Mass Index $>$ $25 \mathrm{~kg} / \mathrm{m}^{2}$ was associated with better improvements [54].



Figure 5: Metabolic reactions in COX, IL-1 signaling pathways and lipooxygenases. FA: Fatty Acid(s); $\mathrm{PGH}_{2}$ : Prostaglandin $\mathrm{H}_{2}$; $\mathrm{PGI}_{2}$ : Prostacyclin; $\mathrm{TXA}_{2}$ : Thromboxane $\mathrm{A}_{2} ; \mathrm{PGD}_{2}$ : Prostaglandin $\mathrm{D}_{2}$; $\mathrm{PGE}_{2}$ : Prostaglandin $\mathrm{E}_{2}$; $\mathrm{PGF}_{2 \mathrm{a}}$ : Prostaglandin $\mathrm{F}_{2 \mathrm{a}}$; HPETE: Hydroperoxy Eicosatetraenoic acids; EET: Epoxyeicosatrienoic acids; LT: Leukotrienes; $\mathrm{PGI}_{3}$ : Prostaglandin $\mathrm{I}_{3}$; $\mathrm{PGA}_{3}$ : Prostaglandin $\mathrm{A}_{3}$; $\mathrm{TXA}_{3}$ : Thromboxane $\mathrm{A}_{3}$; PGF $_{30}$ : Prostaglandin $F_{3 a} ; G S H$ : Glutathione; PLA 2 : Phospholipases $A_{2}$.

Control of lipid metabolism and cholesterol desaturation in the blood has been cited as major factor in cardiovascular disease. The herbiceuticals have been reported as inhibitors of cholesterol synthesis and enhancing HDL lipoproteins in the body. To explain the effect of herbiceuticals, two major mechanisms play significant role in cholesterol saturation and 
lipoprotein synthesis. First, HMG CoA synthase enzyme controls the mevalonate to HMG CoA formation that subsequently used in cholesterol formation while cholesterol oxidase enzyme oxidizes cholesterol to desaturate it. Second, cholesterol esterification by LCAT and ACAT enzymes and subsequently apoprotein binding controls the lipoprotein formation [55-58]. Mainly high density lipoprotein (HDL) plays significant role in scavenging cholesterol from blood as shown in (Figure 5). Low density lipoproteins (LDL) transport is controlled by LDL receptors in the cells.

LDL lipoproteins get metabolized by lipo-oxygenase pathway as shown by (Figure 5). The anti-inflammatory effects and antithrombogenic effects of omega-3 fatty acids are eicosanoiddependent process. More intake of EPA and DHA fatty acids increases these fatty acids in tissue, cellular and circulating lipids, along with a simultaneous reduction in omega- 6 fatty acids. EPA acts as a substrate for both cyclooxygenase (COX) and 5-lipoxygenase (5-LOX) enzymes to make derivatives from arachidonic acid $(\alpha, \beta)$ such as leucotriene B5 (LTB5) is only about $10 \%$ as potent as LTB4 as a chemotactic agent and in promoting lysosomal enzyme release). The omega- 3 fatty acids also result with reduced formation of thomboxane-2 (TxA2) and prostacyclin I2 (PGI2), as AA is a TxA2 and PGI2 precursor and inhibiting platelet aggregation (a less thrombogenic state) as shown in (Figure 5).

\section{The fatty acids display major beneficial effects:}

a. Lipid lowering in blood;

b. Antiarrhythmic effect in CHD;

c. Antithrombotic effects;

d. Anti atherosclerotic and anti-inflammatory effects;

e. Improved endothelial function; and

f. Lowering blood pressure.

From biochemistry standpoint, the beneficial effect of $\beta-3$ fatty acids on blood lipids is by the stimulation of the gene expression of lipoprotein lipase (LPL) enzyme in human adipose tissue with increase in the LPL mRNA. It results with post-heparin LPL activity, in conjunction with the lowering effect of these fatty acids on the triglyceride levels, postprandial lipaemia and the levels of the highly atherogenic, small and dense LDL particles [59]. These fatty acids increase the expression of genes encoding enzymes critical to hepatic and skeletal muscle fatty acid $\beta$-oxidation while repressing genes encoding glycolytic, lipogenic and cholesterolgenic enzymes. This twofold action results in the decrease in lipid synthesis and a subsequent increase in lipid oxidation favorable for nutraceutical intervention.

Despite the fact that the exact mode of action of $\beta-3$ fatty acids is not fully understood, it is speculated that $\beta-3$ fatty acids interact with three nuclear receptors-hepatic nuclear factor (HNF)- $4 \alpha$, liver X receptors (LXR) $\alpha$ and $\beta$ and peroxisome proliferatorsactivated receptors (PPARs) $\alpha, \beta$ and $\gamma$ and by regulating the transcription factor sterol regulatory element binding proteins (SREBPs) 1 and 2 [13]. $\beta$-3 fatty acids also decrease excitability and cytosolic calcium fluctuations of ventricular myocytes via inhibition of $\mathrm{Na}^{+}$and L-type $\mathrm{Ca}^{+2}$ channels. The mechanisms of action of $\beta-3$ fatty acids have not been fully elucidated.

\section{Treatment Recommendations for Herbiceuticals in Cardiovascular Prevention}

\section{Who Need the Alternative Approaches of Herbiceuticals in CVD?}

Children below 18 years probably do not need herbiceuticals. Adults over 20-40 years need herbiceuticals and monitoring CVD. Persons over sixty years in age need CVD/CHD watch and herbiceuticals as mandatory daily dietary supplements in practice. These senior persons may show the following major symptoms as causes of cardiovascular disorders and CVD development [60].

a) Poor cytokines, inflammatory proteins gradually lead to apoptosis, loss of immunity

b) Arteries and veins (and other tissues) become less elastic, as evidenced by our skin. Blood pressure may rise, as arteries lose their elasticity. (The amino acid taurine, found in fish, softens arteries and veins, as well as other connective tissue.)

c) Inflammation and cholesterol-filled growths (plaques) in our blood vessels reduce their rates of flow. The loss of elasticity causes the heart to pump with less power and force.

d) Insulin levels begin to rise as old cells become less responsive to insulin, and the pancreas increases its output to compensate. This eventually leads to Type II diabetes and pancreatic cardiovascular disease in which old cells no longer respond to insulin and end up with heavy cardiovascular damage and cardiovascular disease.

e) Kidneys lose reserve capacity, gradually fail to do normal function and develop cardiovascular disease.

f) Reduced cell mediated immunity and humoral immunity leads to immune deficiency and cardiovascular disorders.

\section{Present State of Art on Herbiceutical Medicine in Cardiovascular Prevention}

FDA requires appropriate scientific evidence regarding safety of nutraceutical use as daily prescription. However, new recommendations suggested that daily diet must contain 6.25 grams of soy protein per serving, micro-compound allicin (a small component of garlic) ad libitum amount, ecosapentanoic acid/docosahexanoic acid as polyunsaturated fatty acids (PUFAs) from fish or fish oils. The complementary medicine and alternative medicine approach is emerging as regulated tool to 
prescribe the norms of herbiceuticals as daily supplements in cardiovascular disease and other diseases [61].

\section{Insurance and Prescription}

National and federal agencies such as NCI and FDA need evidences and established data in large trials to approve herbiceuticals in clinical practice. In lack of such evidences and database, still nutraceutical practice remains at the door steps as nonprescription self-prescription available on counter. As a result, insurance companies still shy to accept herbiceuticals as prescription.

\section{Government Policy: Criteria of Suggested Practice of Herbiceuticals in Cardiovascular Prevention}

The awareness of Complementary and Alternative Medicine (CAM) is increasing rapidly among common public in developed countries [61]. Government agencies are actively participating in safe delivery of bioactive foods and dogwatch if any side effect. Several government reports have showed positive role to introduce new functional foods \& herbiceuticals in CVD/CHD prevention in favor of guava, dietary fibers, soy, phystoesterogens, herbs, cruciferous vegetables [29,34,35]. Both bioactive food and herbiceuticals in diets were suggested as preventive in cardiovascular disease. Main causative factors of cardiovascular disease were free radicals, vitamin C, D, E deficiency, selenium deficiency and loss of cellular immunity in patients on daily diet $[62,63]$. Recently, National Heart and Lung Institute put forth the efforts on alternative ways of cardiovascular disease prevention as public awareness to main focus on life style, prevention and control care measures, eating habits, hazardous contaminants with several successful attempts of antioxidants, garlic, vitamins. Under supervision and dogwatch, most of the bioactive foods on counters and herbiceuticals are marketed as some of them listed in (Table 4).

Table 4: The table represents the FDA approved herbiceuticals and recommended quantity and sources of herbiceuticals on shelf in super markets.

\begin{tabular}{|c|c|c|}
\hline Herbiceuticals & Quantity needed & $\begin{array}{c}\text { Common American } \\
\text { sources }\end{array}$ \\
\hline Aspirin or ibuprofen & Baby aspirin a day & $\begin{array}{l}\text { Nonprescription } \\
\text { counter }\end{array}$ \\
\hline $\begin{array}{l}\text { Chocolate (best if } \\
\text { fat-free) }\end{array}$ & Three servings & $\begin{array}{l}\text { Home-made, Food } \\
\text { emporium }\end{array}$ \\
\hline Grean tea? & Three servings & $\begin{array}{l}\text { Home-made, Food } \\
\text { emporium }\end{array}$ \\
\hline Lycopene & $\begin{array}{l}\text { Cooked tomato } \\
\text { sauces }\end{array}$ & Domino’s Pizza \\
\hline $\begin{array}{l}\text { Fish (tuna, salmon, } \\
\text { mackerel) or } \\
\text { EHA+DHA }\end{array}$ & Two servings a week & $\begin{array}{c}\text { Fresh phytosterols at } \\
\text { Publix }\end{array}$ \\
\hline
\end{tabular}

\begin{tabular}{|c|c|c|}
\hline $\begin{array}{l}\text { Soy 'meat,' cheese, } \\
\text { milk, mozzarella, } \\
\text { sausage, burgers, } \\
\text { broccoli, cabbage, } \\
\text { cauliflower }\end{array}$ & Ad libitum & $\begin{array}{l}\text { Publix, at the edge of } \\
\text { the produce section }\end{array}$ \\
\hline Sulfhydrals & Ad libitum & $\begin{array}{l}\text { Piccadailly's tastes } \\
\text { pretty good }\end{array}$ \\
\hline Blueberries & $\begin{array}{c}\text { A few tablespoons } \\
\text { a day }\end{array}$ & $\begin{array}{l}\text { Publix' frozen foods } \\
\text { (N. side, S. aisle }\end{array}$ \\
\hline Strawberries & $\begin{array}{l}\text { Four or five large } \\
\text { a day }\end{array}$ & $\begin{array}{l}\text { Publix' frozen foods } \\
\text { (N. side, S. aisle }\end{array}$ \\
\hline $\begin{array}{l}\text { Old-fashioned } \\
\text { oatmeal }\end{array}$ & One ounce? & $\begin{array}{c}\text { Publix, all } \\
\text { supermarkets }\end{array}$ \\
\hline Legumes (beans) & Two servings a week & $\begin{array}{c}\text { Publix, all } \\
\text { supermarkets }\end{array}$ \\
\hline $\begin{array}{c}\text { Low-fat blueberries } \\
\text { yogurt }\end{array}$ & $\begin{array}{l}\text { Two or three times } \\
\text { a week }\end{array}$ & $\begin{array}{c}\text { Publix, all } \\
\text { supermarkets }\end{array}$ \\
\hline Yellow vegetables & Ad libitum & $\begin{array}{l}\text { Publix (Piccadilly's } \\
\text { tastes pretty good) }\end{array}$ \\
\hline $\begin{array}{l}\text { Purple grape juice, or } \\
\text { red wine }\end{array}$ & A glass a day & $\begin{array}{l}\text { Publix, for Welsh's } \\
\text { grape juice }\end{array}$ \\
\hline Turmeric roots & Two capsules a day & $\begin{array}{l}\text { GNC natural body } \\
\text { products }\end{array}$ \\
\hline Herbs & Two pills daily & $\begin{array}{c}\text { St John Warts natural } \\
\text { source }\end{array}$ \\
\hline Garlic, soy products & Ad libitum & $\begin{array}{l}\text { Walmart's } \\
\text { 'OneSource' } \\
\text { ampoules }\end{array}$ \\
\hline
\end{tabular}

\section{Bioactive Foods and Herbiceuticals in CVD/CHD: A Survey}

In recentyears during 2002-2016, the major focus was on more evidence based wider use of omega 3 fatty acids combined with multivitamin-multimineral and isolated bioactive components from plants and functional foods in various cardiovascular disease types. In last 4 years maximum efforts were devoted on reviews and compilation of evidenced experimental results on vegetarianism in reducing cardiovascular disease progress and identification of associations of active food components in diet with reduced lipids, myocardial necrosis and apoptosis. However, National Heart and Lung Institute (NHLI) views that sequential events during the nutraceutical treated cell growth or arrest cardiovascular disease are controversial [64]. The use of fish oils in elderly patients was revisited if any relation with arrhythmia and contractility.

The literature during years 2002-2016 suggested major information for following:

a. Direct link of vitamins, minerals in cardiovascular disease prevention;

b. New bioactive food components with new mechanism of lipid lowering;

c. More controlled trials and regulated studies under federal support; 
d. New awareness of unpopular foods and common shelf food supplements in cardiovascular disease prevention;

e. New federal and statuary guidelines on nutraceutical recommended allowances and marketing. The following information is grouped based on literature on herbiceuticals and herbiceuticals in cardiovascular disease management with major focus on controlled randomized trials in experimental cardiovascular diseases and clinical cardiovascular disease subjects. The description is divided into three sections.

\section{Bioactive foods and herbiceuticals in cardiovascular prevention during years 2000-2016:}

Herbiceuticals and local foods were suggested as readily available and their use with possibility of alternative pharmacotherapy to prevent cardiovascular diseases [6466]. Less known bioactive foods containing ephedra and caffeine were reported to improve electrocardiographic and hemodynamic effects [66]. Clear cardio protective role of vitamin E and antioxidant supplements was reviewed in prevention of cardiovascular diseases [67-72]. Homocysteine, taurine, vitamins and omega 3-fatty acids were reinvestigated and confirmed their value in cardiovascular prevention [73-77].

Mechanism of cardiovascular prevention by herbiceuticals: Mainly cholesterol rich dietary fats enhances the risk of coronary heart disease while omega 3/omega 6 fatty acids reduce the risk of cardiovascular diseases and play cardioprotective role in primary, secondary and late- onset diseases [55,56]. Interestingly, the excessive linoleic acid is manifested as 'linoleic acid syndrome' in coronary heart disease $[57,58]$. Conjugated lineleic acid was reported as protective against cardiac hypertrophy [78]. Omega 3 fatty acids mainly lower the blood lipids.

\section{The possible reasons of cardioprotection by omega-3 fatty acids in bioactive herbals:}

i. Lipid lowering (reduction of fasting triglycerides, attenuation of postprandial triglyceride response)

\section{ii. Antiarrhythmic effects}

iii. Antithrombotic and other effects on the haemostatic systems (i.e. reduced platelet reactivity, moderately longer bleeding times, reduced plasma viscosity)

iv. Inhibition of atherosclerosis and inflammation via inhibition of smooth muscle cell proliferation, altered eicosanoid synthesis, reduced expression of cell adhesion molecules and suppression of inflammatory cytokines production (IL's, TNF- $\alpha$ ) and mitogens

v. Improvement of the endothelial function [through enhancement of nitric oxide - dependent and nitric oxide independent vasodilatation]

vi. Improvement in blood pressure (Table 4). a. Aspirin, fish products and ibuprofen act as antiinflammatory properties.

b. Tuna and mackerel contain mercury, dioxin and PCBs. Salmon fish is safe.

\section{CVD/CHD in the human body and herbiceutical protection:}

Supplementation of fish oils dominate the scenario of lipid lowering in cardiovascular diseases [78]. New candidates such as cinnamon, ginko biloba, bioactive peptides have been introduced in the list of herbiceuticals with cardioprotective properties [75,79-81]. In recent detailed report, authors validated that Guggul (Commiphora mukul) herb rich in guggusterones lowers both cholesterol (30\% in 3 months) and triglycerides. It maintains LDL level (35\% lowering in 3 months) and improves HDL level (20\% in 12 weeks) to keep higher HDL/LDL ratio. It keeps smooth blood flow and maintains thin blood with continuous detoxification and reduced platelet aggregation. It relaxes the muscles and keeps muscle strain low. Additionally, it has properties of rejuvenation and blood purification. Other unique properties are immune modulation and lipid lowering. Guggul increases body's metabolic rate, improved thyroid function and heat production due to the presence of guggulsterones [82,83]. Broadly, today it is believed that bioactive foods get digested by natural enzymes and their digested metabolite products target many cardiovascular related intracellular metabolic abnormalities of both focal (targeted cure) and whole body in origin (whole individual or global cure) while its counterpart artificial synthesized pharmaceutical drug either inhibits or elevates only one biochemical reaction with assumption of complete cure. In this single step cure approach, several naturally active enzymes, cofactors and assembly proteins lose their conformation and functionality (bioactive behavior) leading to several side effects. These are lesser by bioactive foods or herbiceuticals because of their wider acceptance in the body but side effects are very frequent caused by pharmaceutical drugs and still it remains a challenge how to minimize these side effects. Several negative studies exist to advocate the further careful investigations $[82,83]$.

\section{Challenges, Hypes, Hopes and Futuristic role of Herbiceuticals in Cardio protection}

Most of the success of herbiceuticals is based on selfprescription and own individual experiences. Still it is far to realize the miraculous benefits of herbiceuticals unless controlled clinical trials support the evidences and facts of nutraceutical preventive therapeutic efficacy. Major challenge is early detection of cardiovascular disease and timely effective treatment. In spite of all tools available, cardiovascular disease is major health hazard. The major available data on nutraceutical benefits in cardiovascular disease comes from epidemiological health and population statistics. The reduced cardiovascular disease incidence due to herbiceuticals seems hype but greater hopes are anticipated with advancements in food science. 
However, still cardiovascular disease remains a major threat because of high mortality compounded with incomplete success of chemotherapy and surgery intervention. In future, bioengineered herbiceuticals will play significant role in CVD prevention as alternative therapeutics.

Bioactive foods with rich herbiceuticals still are growing in number as healthy food products introduced by companies and investigations suggest high hopes of herbiceuticals in cardiovascular disease prevention. The primary focus still remains on dyslipidemia and lipid lowering by fish oils and bioactive herbal foods. The role of governments and globalization will certainly support the health risks and clinical trials on new bioactive herbal foods and herbiceuticals. The herbiceuticals are becoming popular as they are harmless and natural food constituents. The herbiceuticals are still food supplements and last 15 years demonstrated enormous change in the perception of herbiceuticals as cardiovascular disease preventive and therapeutic supplements in cardiovascular diseases. Chinese herbal medicine is making advances in introducing herbs at priority within medical ethics to claim the success of herbs in arresting cardiovascular injury such as hawthorn, cassa italica herbal combinatorial medicine [84-86]. We believe that future trend of curing coronary artery disease will be mixture of complementary approaches such as: optimal medical treatment (vasodilators + antiplatelet agents) --> herbal supplements (Chinese formula or Arjun herbs) -->dietary (L-carnitine, magnesium) -->body physique (exercise, chelation therapy, acupuncture) -->Mind (esteem build up) -->life style change (nonsmoking/non-alcoholic spirit and less drug dependence) with LONGLIVE peaceful life [87-94].

\section{Conclusion}

In present report, herbs are reviewed in possible use as antihypertensive, anti-arrhythmic, cardio protective supplements. The pharmacological action and biochemical mechanisms of herbs are highlighted with examples for their possible antihypertensive, anti-arrhythmic, cardio protective effects on heart tissue and cardio protective action. A possible antihypertensive, anti-arrhythmic cardio protective composition is proposed for make effective cardio protective herbal formula. The focus of paper is to review for comparison of anti antihypertensive, anti-arrhythmic, cardio protective strengths of different herbs in the light of present knowledge. The toxic effects of herbal over intake are highlighted to show their side effects. Finally, the aim is to catch the attention of regulatory government bodies on growing unnoticed use of herbs among large population having no knowledge of herbal side effects they are using. So that government or health authorities can remain vigilant in informing public and insurers in time before it is too late.

\section{Acknowledgement}

Author acknowledges the permission to do advanced level internship at Heart and Vascular Surgery Center, Tallahassee
Memorial Hospital, Mikusukee Road, Tallahassee, Florida for Cardiovascular Technology Research program under Drs. Julian Hurt, Murrah, Al Saint and Khairullah. The author acknowledges the opportunity of engineering and biotechnology internship under supervision of Dr. Ching J. Chen at FAMU-FSU College of Engineering, Tallahassee, Florida.

\section{References}

1. Sheu SJ, Shen CG (2004) Herbal pharmaceutical composition for prophylaxis and/or treatment of cardiovascular diseases and the method of preparing the same.US patent US2004/0234627.

2. Young J (2006) Composition of natural herb extract for treating cardiovascular disease and its method of preparation thereof. US patent 0083798 .

3. Berman DS, Hachamovitch R, Shaw LJ, Friedman JD, Hayes SW, et al. (2006) Roles of Nuclear Cardiology, Cardiac Computed Tomography, and Cardiac Magnetic Resonance. J Nucl Med 47(1): 74-82.

4. Wei QY, Ma JP, Cai YJ, Yang L, Liu ZL (2005) Cytotoxic and apoptotic activities of diarylheptanoids and gingerol-related compounds from the rhizome of Chinese ginger. J Ethnopharmacol 102(2): 177-184.

5. Wei F, Li D, Luo C, Yue H, Chen Q, Huang Z (2004) Pharmaceutical composition for the treatment of cardiovascular and cerebrovascular diseases. US Patent 7438935

6. Sharma R, Singh RB (2004) Human Coronary Artery Lesions: Magnetic Resonance Imaging, NMR Spectroscopy, Histopathology and Oxidative Stress Markers. World Heart J 1(2): 179-184.

7. Sharma R (2011) Antibodies in nanomedicine and bioimaging. Chapter 17 In: Antibody Mediated (mAB) Drug Delivery Systems (DDS): Concepts, Technology and applications. Ed. Pathak Y, Benita S. John Willey and Sons Inc.

8. Sharma R, Singh RB (2010) Bioactive foods and nutraceutical supplementation criteria in cardiovascular protection. The Open Nutrceuticals J 3: 141-153.

9. Haller CA, Anderson IB, Kim SY, Blanc PD (2002) An evaluation of selected herbal reference texts and comparison to published reports of adverse herbal events. Adverse Drug React Toxicol Rev 21(3): 143-150.

10. Warnes CA, Williams RG, Bashore TM, Child JS, Connolly HM, et al. (2008) ACC/AHA 2008 Guidelines for the management of adults with congenital heart disease. J Am Coll Cardiol 52(23): 143-263.

11. Almario RU, Vonghavaravat V, Wong R, Kasim-Karakas SE (2001) Effect of walnut consumption on plasma fatty acids and lipoproteins in combined hyperlipidemia. Am J Clin Nutr 74(1): 72-79.

12. Din JN, Newby DE, Flapan AD (2004) Omega 3 fatty acids and cardiovascular disease - fishing for a natural treatment. BMJ 328(7430): 30-35.

13. Jump DB (2002) Dietary polyunsaturated fatty acids and regulation of gene transcription. Curr Opin Lipidol 13(2): 155-164.

14. Kris-Etheron PM, Harris WS, Appel LJ (2003) Fish consumption, fish oil, omega-3 fatty acids and cardiovascular disease. Arterioscler Thromb Vasc Biol 23(2): e20-e31.

15. Lopez-Garcia E, Schulze MB, Manson JE, Meigs JB, Albert CM, et al. (2004) Consumption of (n-3) fatty acids is related to plasma biomarkers of inflammation and endothelial activation in women. J Nutr 134(7): 1806-1811.

16. Hjerkinn EM, Seljeflot I, Ellingsen I, Berstad P, Hjermann I, et al. (2005) Influence of long-term intervention with dietary counseling, longchain n-3 fatty acid supplements, or both on circulating markers of 


\section{Journal of Cardiology \& Cardiovascular Therapy}

endothelial activation in men with long-standing hyperlipidemia. Am Clin Nutr 81(3): 583-589.

17. De Caterina R, Liao JK, Libby P (2000) Fatty acid modulation of endothelial activation. Am J Clin Nutr 71(1): 213S-223S.

18. Harris WS, Reid KJ, Sands SA, Spertus JA (2007) Blood omega-3 and transfatty acids in middle aged acute coronary syndrome patients. Am J Cardiol 99(2): 154-158.

19. Hu FB, Willett WC (2002) Optimal diets for prevention of coronary heart disease. JAMA 288(20): 2569-2578.

20. Coombes JS, Powers SK, Hamilton KL, Demirel HA, Shanely RA, et al. (2000) Improved cardiac performance after ischemia in aged rats supplemented with vitamin E and alpha-lipoic acid. Am J Physiol Regul Integr Comp Physiol 279(6): R2149-R2155.

21. Oudit GY, Trivieri MG, Khaper N, Husain T, Wilson GJ, et al. (2004) Taurine supplementation reduces oxidative stress and improves cardiovascular function in an iron-overload murine model. Circulation 109(15): 1877-1885.

22. Racasan S, Braam B, Van der Giezen DM, Goldschmeding R, Boer P, et al (2004) Perinatal Larginine and antioxidant supplements reduce adult blood pressure in spontaneously hypertensive rats. Hypertension 44(1): 83-88.

23. Wang Q, Simonyi A, Li W, Sisk BA, Miller RL, et al. (2005) Dietary grape supplement ameliorates cerebral ischemia-induced neuronal death in gerbils. Mol Nutr Food Res 49(5): 443-451.

24. Zhou J, Møller J, Ritskes-Hoitinga M, Larsen ML, Austin RC, et al. (2003) Effects of vitamin supplementation and hyperhomocysteinemia on atherosclerosis in apoE-deficient mice. Atherosclerosis 168(2): 255262

25. Zampolli A, Bysted A, Leth T, Mortensen A, De Caterina R, et al. (2006) Contrasting effect of fish oil supplementation on the development of atherosclerosis in murine models. Atherosclerosis 184(1): 78-85.

26. El-Badry AM, Moritz W, Contaldo C, Tian Y, Graf R, et al. (2007) Prevention of reperfusion injury and microcirculatory failure in macrosteatotic mouse liver by omega-3 fatty acids. Hepatology 45(4) 855-863.

27. Esterhuyse AJ, Toit ED, Rooyen JV (2005) Dietary red palm oil supplementation protects against the consequences of global ischemia in the isolated perfused rat heart. Asia Pac J Clin Nutr 14(4): 340-347.

28. Zahid AM, Hussain ME, Fahim M (2005) Antiatherosclerotic effects of dietary supplementations of garlic and turmeric: restoration of endothelial function in rats. Life Sci 77(8): 837-857.

29. Singh RB, Rastogi SS, Niaz MA, Ghosh S, Singh R, et al. (1992) Effect of fat modified and fruits and vegetable enriched diets on blood lipids in the Indian diet heart study. Am J Cardiol 70(9): 869-874.

30. Samuel SM, Thirunavukkarasu M, Penumathsa SV, Paul D, Maulik N (2008) Akt/FOXO3a/SIRT1-mediated cardioprotection by n-tyroso against ischemic stress in rat in vivo model of myocardial infarction: switching gears toward survival and longevity. J Agric Food Chem 56(20): 9692-9698.

31. Nilsen DW, Albrektsen G, Landmark K, Moen S, Aarsland T, et al (2001) Effects of a high dose concentrate of n-3 fatty acids or corn oil introduced after an acute myocardial infarction on serum triglycerides and HDL cholesterol. Am J Clin Nutr 57: 193-200.

32. Singh RB, Dubnov G, Niaz MA, Ghosh S, Singh R, et al. (2002) Effect of an Indo-Mediterranean diet on progression of coronary disease in high risk patients: a randomized single blind trial. Lancet 360: 1455-1461.

33. Obarzanek E, Sacks FM, Vollmer WM, Bray GA, Miller ER, et al. (2001) Effects on blood lipids of a blood pressure-lowering diet: the Dietary Approaches to Stop Hypertension (DASH) Trial. Am J Clin Nutr 74(1):
80-89.

34. Singh RB, Rastogi SS, Ghosh S, Singh R, Niaz MA (1992) Effects of guava intake on serum total and high density lipoprotein cholesterol levels and on systemic blood pressure. Am J Cardiol 70(15): 1287-1291.

35. Singh RB, Sharma VK, Gupta RK (1992) Nutritional modulators of lipoprotein metabolism in patients with risk factors for coronary heart disease. J Am Coll Nutr 11(4): 391-398.

36. Sampath H, Ntambi JM (2004) Polyunsaturated fatty acid regulation of gene expression. Nutr Rev 62(9): 333-339.

37. Kim HJ, Takahashi M, Ezaki O (1999) Fish oil feeding decreases mature sterol regulatory element-binding protein 1 [SREBP-1] by dowregulation of SREBP-1c mRNA in mouse liver. A possible mechanism for down - regulation of lipogenic enzyme mRNAs. J Biol Chem 274(36): 25892-25898.

38. Leaf A, Kang JX, Xiao YF, Billman GE (2003) Clinical prevention of sudden cardiac death by n-3 polyunsaturated fatty acid mechanism of prevention arrhythmias by n-3 fish oils. Circulation 107(21): 26462452.

39. De Caterina R, Madonna R, Zucchi R, La Rovere MT (2003) Antiarrhythmic effects of omega- 3 fatty acids: from epidemiology to bedside. Am Heart J 146(3): 420-430.

40. Connor WE, De Franchesco CA, Connor SL (1993) N-3 fatty acids from fish oil: effects on plasma lipoproteins and hypertriglyceridemic patients. Ann N Y Acad Sci 683: 16-34.

41.Zampelas A, Peel AS, Gould BJ, Wright J, Williams CM (1994) Polyunsaturated fatty acids of the n- 6 and n-3 series: effects on postprandial lipid and apolipoprotein levels in healthy men. Eur J Clin Nutr 48(12): 842-848.

42. Abeywardena MY, Head RJ (2001) Long chain n-3 polyunsaturated fatty acids and blood vessel function. Cardiovasc Res 52(3): 361-371.

43. Hooper L, Thompson RL, Harrison RA, Summerbell CD, Ness AR, et al. (2006) Risks and benefits of omega 3 fats for mortality, cardiovascular disease, and cancer: Systematic review. BMJ 332(544): 752-755.

44. Thirunavukkarasu M, Penumathsa SV, Juhasz B, Zhan L, Cordis G, et al (2006) Niacinbound chromium enhances myocardial protection from ischemiareperfusion injury. Am J Physiol Heart Circ Physiol 291(2): H820-826.

45. Roche HM, Gibney MJ (2000) Effect of long-chain n-3 polyunsaturated fatty acids on fasting and postprandial triacylglycerol metabolism. Am J Clin Nutr 71(1): 232S-237S.

46. Matsui H, Shimosawa T, Uetake Y, Wang H, Ogura S, et al. (2006) Protective effect of potassium against the hypertensive cardiac dysfunction: association with reactive oxygen species reduction. Hypertension 48(2): 225-231.

47. Dallner G, Brismar K, Chojnacki T, Swiezewska E (2003) Regulation of coenzyme $\mathrm{Q}$ biosynthesis and breakdown. Biofactors 18(1-4): 11-22.

48. Harris A, Devaraj S, Jialal I (2002) Oxidative stress, alpha-tocopherol therapy, and atherosclerosis. Curr Atheroscler Rep 4(5): 373-380.

49. Calder PC (2004) n-3 Fatty acids and cardiovascular disease: evidence explained and mechanisms explored. Clin Sci (Lond) 107(1): 1-11.

50. Santo AS, Santo AM, Browne RW, Burton H, Leddy JJ, et al. (2010) Postprandial lipemia detects the effect of soy protein on cardiovascular disease risk compared with the fasting lipid profile. Lipids. 45(12): 1127-1138.

51. Basu A, Lucas EA (2007) Mechanisms and effects of green tea on cardiovascular health. Nutr Rev 65(8): 361-375.

52. Gurley BJ, Swain A, Hubbard MA, Williams DK, Barone G, et al. (2008) Clinical assessment of CYP2D6-mediated herb-drug interactions in 


\section{Journal of Cardiology \& Cardiovascular Therapy}

humans: effects of milk thistle, black cohosh, goldenseal, kava kava, St. John's wort, and Echinacea. Mol Nutr Food Res 52(7): 755-763.

53. Slavin JL (2008) Position of the American Dietetic Association: health implications of dietary fiber. J Am Diet Assoc 108(10): 1716-1731.

54. Chagan L, Bernstein D, Cheng JW, Kirschenbaum HL, Rozenfeld V, et al. (2005) Use of biological based therapy in patients with cardiovascular diseases in a university hospital in New York City. BMC Complement Altern Med 5: 4

55. Okuyama H, Ichikawa Y, Sun Y, Hamazaki T, Lands WE (2007) The cholesterol hypothesis - its basis and its faults. World Rev Nutr Diet 96: 1-17.

56. Okuyama H, Ichikawa Y, Sun Y, Hamazaki T, Lands WE (2007) New directions of lipid nutrition for the primary and secondary prevention of coronary heart disease and other late-onset diseases. World Rev Nutr Diet 96: 151-158.

57. Okuyama H, Ichikawa Y, Sun Y, Hamazaki T, Lands WE (2007) Mechanisms by which dietary fats affect coronary heart disease mortality. World Rev Nutr Diet 96: 119-141.

58. Okuyama H, Ichikawa Y, Sun Y, Hamazaki T, Lands WE (2007) Omega3 fatty acids effectively prevent coronary heart disease and other late onset diseases - the excessive linoleic acid syndrome. World Rev Nutr Diet 96: 83-103.

59. Khan S, Minihane AM, Talmud PJ, Wright JW, Murphy MC, et al. (2002) Dietary long-chain n-3 PUFA's increase LPL gene expression in adipose tissue of subjects with an atherogenic lipoprotein phenotype. J Lipid Res 43(6): 979-985

60. Mozaffarian D, Psaty BM, Rimm EB, Lemaitre RN, Burke GL, et al. (2004) Fish intake and risk of incident of atrial fibrillation. Circulation 110(4): 368-373.

61. Lane JS, Magno CP, Lane KT, Chan T, Hoyt DB, et al. (2008) Nutrition impacts the prevalence of peripheral arterial disease in the United States. J Vasc Surg 48(4): 897-904.

62. MRC/BHF Heart Protection Study of cholesterol-lowering therapy and of antioxidant vitamin supplementation in a wide range of patients at increased risk of coronary heart disease death: early safety and efficacy experience. Eur Heart J 1999; 20(10): 725-741.

63. Heinrich M, Leonti M, Nebel S, Peschel W (2005) Local Food Nutraceuticals: an example of a multidisciplinary research project on local knowledge. J Physiol Pharmacol 56(S1): 5-22.

64. Chagan L, Ioselovich A, Asherova L, Cheng JW (2002) Use of alternative pharmacotherapy in management of cardiovascular diseases. Am J Manag Care 8(3): 270-285.

65. Wildman REC (2001) Classifying nutraceuticals. In: Wildman REC, Ed. handbook of nutraceuticals and functional foods. CRC series in modern nutrition 13-30.

66. Eastwood MA (1999) Interaction of dietary antioxidants in vivo: how fruit and vegetables prevent disease? QJM 92(9): 527-530.

67. Borochov-Neori H, Judeinstein S, Greenberg A, Fuhrman B, Attias J, et al. (2008) Phenolic antioxidants and antiatherogenic effects of Marula (Sclerocarrya birrea Subsp. caffra) fruit juice in healthy humans. Agric Food Chem 56(21): 9884-9891.

68. Maxwell SR (2000) Coronary artery disease--free radical damage, antioxidant protection and the role of homocysteine. Basic Res Cardiol 95(1): I65-171.

69. McBride BF, Karapanos AK, Krudysz A, Kluger J, Coleman CI, et al. (2004) Electrocardiographic and hemodynamic effects of a multicomponent dietary supplement containing ephedra and caffeine: a randomized controlled trial. JAMA 291(2): 216-221.

70. Pham DQ Plakogiannis R (2005) Vitamin E supplementation in cardiovascular disease and cancer prevention: Part 1. Ann Pharmacother 39(11): 1870-1878.

71. Tran TL (2001) Antioxidant supplements to prevent heart disease. Real hope or empty hype? Postgrad Med 109(1): 109-114

72. Carlsson CM (2006) Homocysteine lowering with folic acid and vitamin B supplements: effects on cardiovascular disease in older adults. Drugs Aging 23(6): 491-502.

73. Erdmann K, Cheung BW, Schröder H (2008) The possible roles of foodderived bioactive peptides in reducing the risk of cardiovascular disease. J Nutr Biochem 19(10): 643-654

74. Marchioli R, Barzi F, Bomba E, Chieffo C, Di Gregorio D, et al. (2002) Early protection against sudden death by n-3 polyunsaturated fatty acids after myocardial infarction: time-course analysis of the results of the Gruppo Italiano per lo Studio della Sopravvivenza nell'Infarto Miocardico (GISSI)-Prevenzione. Circulation 105(16): 1897-1903.

75. McCarty MF (2004) A taurine-supplemented vegan diet may blunt the contribution of neutrophil activation to acute coronary events. Med Hypotheses 63(3): 419-425.

76. Simopoulos AP (2003) Importance of the ratio of omega-6/omega-3 essential fatty acids: evolutionary aspects. World Rev Nutr Diet 92: $1-22$.

77. Malinowski JM, Metka K (2007) Elevation of low-density lipoprotein cholesterol concentration with over-the-counter fish oil supplementation. Ann Pharmacother 41(7): 1296-1300.

78. Alibin CP, Kopilas MA, Anderson HD (2008) Suppression of cardiac myocyte hypertrophy by conjugated linoleic acid: role of peroxisome proliferator-activated receptors alpha and gamma. J Biol Chem 283(16): 10707-10715.

79. Baker WL, Gutierrez-Williams G, White CM, Kluger J, Coleman CI (2008) Effect of cinnamon on glucose control and lipid parameters. Diabetes Care 31(1): 41-43.

80. Nohr LA, Rasmussen LB, Straand J (2009) Resin from the mukul myrrh tree, guggul, can it be used for treating hypercholesterolemia? A randomized, controlled study. Complement Ther Med 17(1): 16-22.

81. Szapary PO, Wolfe ML, Bloedon LT, Cucchiara AJ, DerMarderosian AH, et al. (2003) Guggulipid for the treatment of hypercholesterolemia: a randomized controlled trial. J Am Med Assoc 290(6): 765-772.

82. An W, Yang J (2006) Protective effects of Ping-Lv-Mixture (PLM), a medicinal formula on arrhythmias induced by myocardial ischemiareperfusion. J Ethnopharmacol 108(1): 90-95.

83. El-Menyar AA, Helmy AH, Mubarak NM, Arafa SE (2006) Acute myocardial infarction with patent epicardial coronary vessels following Cassia italica ingestion. Cardiovasc Toxicol 6(2): 81-84.

84. Gao ZY, Zhang JC, Xu H, Shi DZ, Fu CG, et al. (2010) Analysis of relationships among syndrome, therapeutic treatment, and Chinese herbal medicine in patients with coronary artery. Zhong Xi Yi Jie He Xue Bao 8(3): 238-243.

85. Jia Y, Sun X, Jia M, Cui Z, Li C (2001) One hundred and seven middleaged and senile cases of coronary heart disease with ventricular premature beat treated by qing xin an shen fang. J Tradit Chin Med 21(4): 247-251.

86. Tam WY, Chook P, Qiao M, Chan LT, Chan TY, et al. (2009) The efficacy and tolerability of adjunctive alternative herbal medicine (Salvia miltiorrhiza and Pueraria lobata) on vascular function and structure in coronary patients. J Altern Complement Med 15(4): 415-421.

87. Agirbasli M, Guney A, Ozturhan H, Agirbasli D, Ulucan K, et al. (2011) Multifactor dimensionality reduction analysis of MTHFR, PAI-1, ACE, PON1, and eNOS gene polymorphisms in patients with early onset coronary artery disease. Eur J Cardiovasc Prev Rehabil. 
88. Amin KA, Kamel HH, Abd Eltawab MA (2011) Protective effect of Garcinia against renal oxidative stress and biomarkers induced by high fat and sucrose diet. Lipids Health Dis 10: 6.

89. El-Menyar AA, Helmy AH, Mubarak NM, Arafa SE (2006) Acute myocardial infarction with patent epicardial coronary vessels following Cassia italica ingestion. Cardiovasc Toxicol 6(2): 81-84.

90. Ghosh SS, Salloum FN, Abbate A, Krieg R, Sica DA, et al. (2010) Curcumin prevents cardiac remodeling secondary to chronic renal failure through deactivation of hypertrophic signaling in rats. Am J
Physiol Heart Circ Physiol 299(4): H975-984

91. Hietala AM, Solheim H, Fossdal CG (2008) Real-time PCR-based monitoring of DNA pools in the tri-trophic interaction between Norway spruce, the rust Thekopsora areolata, and an opportunistic ascomycetous Phomopsis sp. Phytopathology 98(1): 51-58.

92. Massaro M, Scofitti E, Carluccio MA, De Caterina R (2008) Basic mechanisms behind the effects of n-fatty acids on cardiovascular disease. Prostaglandins Leukot Essent Fatty Acid 79(3-5): 109-115.

\section{Your next submission with Juniper Publishers will reach you the below assets}

- Quality Editorial service

- Swift Peer Review

- Reprints availability

- E-prints Service

- Manuscript Podcast for convenient understanding

- Global attainment for your research

- Manuscript accessibility in different formats

( Pdf, E-pub, Full Text, Audio)

- Unceasing customer service

Track the below URL for one-step submission https://juniperpublishers.com/online-submission.php 